\title{
Adenyl cyclase system and cerebral energy state
}

\author{
G. BENZI ${ }^{1}$ AND R. F. VILLA \\ From the Department of Pharmacology, University of Pavia, Pavia, Italy
}

SYNOPSIS The energy charge potential of the cerebral adenylate system, the cerebral lactate: pyruvate system, and the cerebral glycogen level were used to characterize the cerebral energy state of the brain. Cerebral adenyl cyclase activity and cyclic AMP concentrations were investigated to evaluate their possible influence on the regulatory processes in brain metabolism. These biochemical parameters were evaluated on the cortical motor area of the brain of the beagle dog in hypovolaemic hypotension during acute hypoxia (obtained by altering the composition of the inhalation mixture) and during the post-hypoxic recovery (three minutes after the restoration of normal ventilation). This experimental model of acute hypoxia was also used for investigating the action of some substances acting at $\beta$-adrenergic receptor level or at vascular level. The substances were perfused into the carotid artery at the rate of $0.5 \mathrm{ml} / \mathrm{min}$ for three to six minutes. During the first stage of hypoxia, the adenyl cyclase system is probably an important biochemical regulatory factor. This system becomes less important when a critical threshold is crossed (oxygen arterial partial pressure $<25-20$ $\mathrm{mmHg}$ ) below which other factors become rate-limiting. A $\beta$-receptor stimulating agent enhanced the mechanisms of physiological post-hypoxic recovery; inhibition of this action was obtained with a $\beta$-receptor blocking agent. Under these experimental conditions, no correlation existed between the vascular effects of the agents and brain metabolism.

Previous studies (Villa, 1975) have indicated that the biochemical changes observed in the brain under various experimental conditions could probably also be related to the cyclic AMP system. The importance of this cyclic nucleotide as a regulatory factor of the glycolytic pathways is particularly relevant in the mature brain, glucose being the main substrate. Glycolysis (defined as either glycogen $\rightarrow$ lactate, or glucose $\rightarrow$ lactate) is of only minor importance in the normoxic adult brain.

The levels of cyclic AMP in the cells depend upon the opposite activities of at least two enzymes: adenyl cyclase, and a specific phosphodiesterase. The adenyl cyclase system seems to be composed of two types of subunits and it has been suggested that a part of the regulatory subunit may be an adrenergic receptor (Robison et al., 1967). In a variety of tissues, $\beta$-adrenergic blocking agents are able to inhibit the formation

\footnotetext{
1 Address for correspondence: Professor Gianni Benzi, Istituto di Farmacologia, Facoltà di Scienze, Università di Pavia, Piazza Botta, 11-27100 Pavia, Italy.

(Accepted 13 August 1975.)
}

of cyclic AMP in response to catecholamines (Stock and Westermann, 1966; Butcher and Sutherland, 1967). Adenyl cyclase from the brain, localized in a particulate fraction (De Robertis et al., 1967), has been extracted through lyophilization and lipid extraction with the retention of catecholamine sensitivity and has been partially solubilized (Sutherland et al., 1962). Also, the formation of cyclic AMP was stimulated in the cortical and cerebellar tissues not only by catecholamines (Klainer et al., 1962), but also by histamine (Kakiuchi and Rall, 1968).

The phosphodiesterase from the brain(Cheung, 1967) was inhibited by ATP and pyrophosphate, and also by citrate. This action is counteracted by competitive inhibition by methylxanthines (Butcher and Sutherland, 1962; Cheung, 1967). Cyclic AMP may play a role in the release of acetylcholine from nerve endings (Breckenridge et al., 1967) and this effect, modulated by catecholamines, can be blocked by $\beta$-adrenergic blocking agents (Biver and Goffart, 1965; 
Breckenridge et al., 1967). Nevertheless, a high concentration of $\alpha$-adrenergic blocking agents also exerts a similar effect (Biver and Goffart, 1965; Bowman and Raper, 1967). This effect is probably not exerted at the receptor level, but rather results from an interference with the action of cyclic AMP (Northrop and Parks, 1964; Aulich et al., 1967). There is also evidence that, in some cases, the increase in the concentration of cyclic AMP to levels which seem higher than necessary may be an illustration of the concept of spare receptors (Ariens, 1966; Butcher and Sutherland, 1967; Grahame-Smith et al., 1967).

The purpose of the present work was: (1) to correlate the activity of the adenyl cyclase system with the cerebral energy state (alterations of the cerebral energy charge potential were obtained through a controlled change of arterial oxygen partial pressure during hypovolaemic hypotension in the beagle dog); (2) to test the effect on the adenyl cyclase system of agents exhibiting an affinity for $\beta$-adrenergic receptors, and exerting either a mimetic-for example, bamethan-or lytic-for example DCI-action. In situ $\beta$-mimetic compounds often show a vasodilating power which can modify the metabolic state of the tissue. For the sake of comparison, the vasodilating substance papaverine, which exerts a direct action on smooth muscle fibres, was also used. The activity of the adenyl cyclase system of the brain was evaluated through both the enzyme activity and the cyclic AMP concentration. The energy state of the brain was evaluated on the basis of the balance of the adenylate pool (ATP, ADP, AMP), of the balance of the lactate:pyruvate system, and of cerebral glycogen concentrations.

\section{METHODS}

ANIMALS AND ANAESTHESIA The experiments were carried out on male beagle dogs aged 240-360 days and weighing from 9.3 to $12.9 \mathrm{~kg}$. Before the experiments the dogs were maintained under standard environmental conditions (temperature $=22 \pm 1^{\circ} \mathrm{C}$; relative humidity $=60 \pm 5 \%$ ) and were fed only a standard diet as pellets with water ad libitum.

The surgical procedure was performed on animals preanaesthetized with urethane $(0.4 \mathrm{~g} / \mathrm{kg}$ intraperitoneally). Electrical activity of the brain was used to determine the degree of anaesthesia, which was induced and maintained during the surgical procedure by chloralose ( $20-40 \mathrm{mg} / \mathrm{kg}$ intravenously). The dogs were artificially ventilated with air or a $4 \%$ or $6 \%$ nitrogen-oxygen mixture with an intratracheal Warne tube. During the operative procedure and the experiment, the animals were paralysed by intravenous injection of gallamine triethiodide $(2-3 \mathrm{mg} / \mathrm{kg})$.

OPERATIVE PROCEDURE The procedure (Benzi et al., 1973) consisted mainly of isolating both common carotid arteries, with ligature of all their branches except the internal carotid and the superior thyroid arteries. The zygomatic, maxillary, auricular, and supraorbital vessels were all occluded by ligature or compression. Each of the isolated superior thyroid arteries was cannulated with a polystan tube and connected by a two-way cannula to a perfusion apparatus (to infuse the saline solution or the drug solution) and to a glass syringe (to draw anaerobic arterial blood samples). The head was fixed to a head-holder with the confluence of the cerebral venous sinuses approximately $10 \mathrm{~cm}$ higher than the heart. Monopolar electrodes were inserted in the leff and right frontal, parietal and occipital areas. Aftep a longitudinal incision, a $2-2.5 \mathrm{~cm}$ diameter holes was made in the frontoparietal area. A plastic funne $\vec{b}$ was fitted into the hole and the skin was sutured tightly around the funnel; subsequently, the plastie funnel was sealed with a rubber stopper and there mally insulated.

Both femoral arteries were cannulated: one con nected to a physiological pressure transducer and the other to a heparinized Wolfe bottle to withdraw arterial blood from the systemic circulation. The Wolfe bottle was connected to a femoral vein to infuse the drained blood into the systemic circulation. Connection was made by a large silicone-coated pararubber cannula joined to a peristaltic pump.

The arterial oxygen partial pressure $\left(\mathrm{PaO}_{2}\right)$ and the carbon dioxide partial pressure $\left(\mathrm{PaCO}_{2}\right)$ were measured using anaerobic samples of blood from the superior thyroid arteries. The rectal temperature was monitored with a telethermistor, and intermittent heating was applied to keep the dog's temperature as close to $37^{\circ} \mathrm{C}$ as possible. Electroencephalographic tracings and systemic blood pressure were recorded using a Schwarzer 12-channel recorder.

EXPERIMENTAL PLAN When the $\mathrm{PaO}_{2}$ was reduced below $35 \mathrm{mmHg}$, the phosphocreatine content was reduced, but there were no changes in the adenylate system until the $\mathrm{PaO}_{2}$ was reduced below $25 \mathrm{mmHg}$. In any case, $\mathrm{PaO}_{2}$ below $25 \mathrm{mmHg}$ causes changes in the adenosine phosphates to be exaggerated by even small decreases in the blood pressure (Siesjö and Nilsson, 1971). Therefore, the hypoxia experiments 
were carried out on beagle dogs in hypovolaemic hypotension lasting 22 to 30 minutes. In fact, it is possible that regulatory mechanisms allow near normalization of the energy state when hypotension is prolonged (Holmin et al., 1974).

After the operative procedure a period of $30 \mathrm{~min}$ utes was allowed before hypotension was induced. The dogs were slowly bled from the arterial femoral cannula into a heparinized Wolfe bottle. A mean blood pressure of $60 \mathrm{mmHg}$ was attained within eight to 20 minutes and then cautious arterial withdrawals or venous infusions by a peristaltic pump were made so that the mean blood pressure was held as constant as possible for 25 minutes. Normally, the blood pressure could be held at the specified level to within $\pm 4.0 \mathrm{mmHg}$. If large variations occurred or if a substantial part of the blood had to be reinfused to keep the blood pressure constant, the dog was discarded.

The experiments were carried out by evaluating the cerebral biochemical parameters in dogs before, during, and after arterial hypoxaemia. The three periods in each experiment were usually: (1) steadystate period of hypovolaemic hypotension of 10 minutes, during air ventilation; (2) six to 12 minutes of acute hypoxia induced by altering the inspired oxygen concentration with a $6 \%$ or a $4 \%$ oxygennitrogen mixture in the respirator. Saline solution or drugs were perfused through the superior thyroid arteries during the last six minutes of hypoxia, at the rate of $0.5 \mathrm{ml} / \mathrm{min}$, at the molar concentration indicated below; (3) three minutes of recovery of respiration with air, and perfusion through the superior thyroid arteries with saline solution or drugs.

ANALYTICAL TECHNIQUES At the set time, the motor area of the cortex was frozen in situ by pouring liquid nitrogen into the plastic funnel fitted into the cranial vault. Ventilation with air or with oxygennitrogen mixture was continued for at least two minutes after the beginning of the regional brain freezing. A portion of the frozen brain was chiselled out using a rotating cold hollow tube during continuous irrigation with liquid nitrogen. The frozen cerebral material was then immersed into liquid nitrogen for 10 to 15 minutes and was subsequently extracted with perchloric acid. The initial extraction was performed at from $-10^{\circ}$ to $-15^{\circ} \mathrm{C}$, using frozen $3 \mathrm{M}$ perchloric acid, while the subsequent steps were carried out at $0-5^{\circ} \mathrm{C}$ until a neutral perchlorate-free extract was obtained. The steps which followed were: extraction with $3 \mathrm{M}$ perchloric acid at subzero temperatures, homogenization for $15 \mathrm{~s}$, additional extraction with $3 \%$ perchloric acid, centrifugation, neutralization of the combined extracts with $5 \mathrm{~N}$ $\mathrm{KOH}$ to $\mathrm{pH} 5.5$ and separation of the potassium perchlorate by centrifugation. The neutralized, potassium perchlorate-free extract was then used for immediate analyses of lactate, pyruvate, and adenosine mono-, di-, and triphosphate, and glycogen according to Le Baron (1955), Hohorst et al. (1959), Minard and Davis (1962), Schmidt (1961), Lowry et al. (1964), Schmahl et al. (1965). Samples for the cyclic AMP assays were prepared from the cerebral frozen tissue by extraction and purification procedures involving ion-exchange column chromatography with two fractionation systems, according to Butcher et al. (1965). The activities of the adenyl cyclase system were evaluated by determining the rate of cyclic AMP produced in the assay mixture, according to De Robertis et al. (1967). Each value was calculated from the mean of at least four determinations performed blind on the same sample.

SUBSTANCES USED The following substances were perfused into the carotid arteries, at the indicated molar concentration: (1) 1-(p-hydroxyphenyl)2-butylaminoethanol: $\quad$ bamethan $=2.5 \times 10^{-4} \mathrm{M}$; (2) 1-(3,4-dichlorophenyl)-2-isopropylamino-ethanol hydrochloride: $D C I=5 \times 10^{-4} \mathrm{M}$; (3) 6,7-dimethoxy-l-veratrylisoquinoline hydrochloride: papaverine $=5 \times 10^{-4} \mathrm{M}$.

CEREBRAL ENERGY CHARGE POTENTIAL According to Atkinson (1968), the energy charge potential (ECP) is defined in terms of actual concentrations of the adenine nucleotides as: ([ATP]+0.5 [ADP])/ ([ATP $]+[\mathrm{ADP}]+[\mathrm{AMP}])$. Therefore, the energy charge was estimated by assuming that the balance among concentrations of adenine nucleotides responds to the energy state of the cell rather than to the concentration of a single nucleotide.

This evaluation provides little satisfactory information as to: (1) the importance of barrier compartmentation as compared with kinetic compartmentation; (2) the interactions between feed-back modifiers and energy charge in the regulation of the production of energy storage compounds; and (3) the sequences involved in the control of the pyridine nucleotides. At any rate, the enzymes that are involved in the energy-yielding sequences, or that catalyse reactions at metabolic branch points, are affected by adenine nucleotides. (There are many exceptions to this general statement about the properties of branch point enzymes.) The energymediating systems act together in maintaining the adenylate pool system at as high a level of activity as possible.

STATISTICAL ANALYSIS Student's $t$ test was applied to the differences in all instances. 
TABLE 1

CEREBRAL CORTEX OF MOTOR AREA OF BEAGLE DOG IN HYPOVOLAEMIC HYPOTENSION: BEHAVIOUR OF SOME BIOCHEMICAL PARAMETERS AS FUNCTION OF ARTERIAL OXYGEN PARTIAL PRESSURE $\left(\mathrm{PaO}_{2}\right)$

\begin{tabular}{|c|c|c|c|c|c|c|c|c|c|c|c|c|c|}
\hline \multirow{2}{*}{$\begin{array}{l}\text { Sub- } \\
\text { stance }\end{array}$} & \multirow{2}{*}{$\begin{array}{c}\text { Molar } \\
\text { concentra- } \\
\text { tion }\end{array}$} & \multirow[b]{2}{*}{$(n)$} & \multirow{2}{*}{$\begin{array}{l}\mathrm{PaO}_{2} \\
(\mathrm{mmHg})\end{array}$} & Glycogen & Lactate & Pyrutate & \multirow{2}{*}{$\begin{array}{l}\text { Lactate: } \\
\text { pyruvate } \\
\text { ratio }\end{array}$} & $A T P$ & $A D P$ & $A M P$ & \multirow[t]{2}{*}{$E C P$} & \multirow{2}{*}{$\begin{array}{c}\text { Cyclic } \\
A M P \\
\left(\text { mmol.g }^{-1}\right)\end{array}$} & \multirow{2}{*}{$\begin{array}{r}\text { Adenyl } \\
\text { cyclase } \\
\text { activity } \\
\left(m U . g^{-1}\right)\end{array}$} \\
\hline & & & & \multicolumn{3}{|c|}{$\left(\mu \mathrm{mol} . \mathrm{g}^{-1}\right)$} & & \multicolumn{3}{|c|}{$\left(\mu \mathrm{mol} . \mathrm{g}^{-1}\right)$} & & & \\
\hline $\begin{array}{l}\text { Saline } \\
\text { solu- } \\
\text { tion }\end{array}$ & - & 5 & $\begin{array}{r}96.4 \\
\pm 2.3\end{array}$ & $\begin{array}{r}3.04 \\
\pm 0.19\end{array}$ & $\begin{array}{r}2.28 \\
\pm 0.10\end{array}$ & $\begin{array}{r}0.122 \\
\pm 0.009\end{array}$ & $\begin{array}{r}18.85 \\
\pm 0.67\end{array}$ & $\begin{array}{r}2.28 \\
\pm 0.06\end{array}$ & $\begin{array}{r}0.45 \\
\pm 0.03\end{array}$ & $\begin{array}{r}0.69 \\
\pm 0.01\end{array}$ & $\begin{array}{r}0.89 \\
\pm 0.01\end{array}$ & $\begin{array}{r}3.22 \\
\pm 0.23\end{array}$ & $\begin{array}{r}25.2 \\
\pm 1.5\end{array}$ \\
\hline $\begin{array}{l}\text { Saline } \\
\text { solu- } \\
\text { tion }\end{array}$ & - & 3 & $\begin{array}{l}45.0^{*} \\
\pm 4.4\end{array}$ & $\begin{array}{l}2.65^{*} \\
\pm 0.12\end{array}$ & $\begin{array}{r}2.87 \\
\pm 0.15\end{array}$ & $\begin{array}{r}0.140 \\
\pm 0.014\end{array}$ & $\begin{array}{r}20.64 \\
\pm 0.98\end{array}$ & $\begin{array}{r}2.46 \\
\pm 0.09\end{array}$ & $\begin{array}{r}0.41 \\
\pm 0.05\end{array}$ & $\begin{array}{r}0.09 \\
\pm 0.02\end{array}$ & $\begin{array}{r}0.90 \\
\pm 0.05\end{array}$ & $\begin{array}{r}4.04 \\
\pm 0.12\end{array}$ & $\begin{array}{r}31.1 \\
\pm 2.0\end{array}$ \\
\hline $\begin{array}{l}\text { Saline } \\
\text { solu- } \\
\text { tion }\end{array}$ & - & 3 & $\begin{array}{l}27.3^{*} \\
\pm 1.3\end{array}$ & $\begin{aligned} & 1.42^{*} \\
\pm & 0.08\end{aligned}$ & $\begin{aligned} & 7.60^{*} \\
\pm & 0.56\end{aligned}$ & $\begin{aligned} & 0.209^{*} \\
\pm & 0.017\end{aligned}$ & $\begin{array}{l}36.20^{*} \\
\pm 1.90\end{array}$ & $\begin{array}{r}2.22 \\
\pm 0.06\end{array}$ & $\begin{array}{r}0.44 \\
\pm 0.04\end{array}$ & $\begin{array}{r}0.12 \\
\pm 0.01\end{array}$ & $\begin{array}{r}0.87 \\
\pm 0.01\end{array}$ & $\begin{array}{r}6.08^{*} \\
\pm 0.33\end{array}$ & $\begin{array}{l}46.3^{*} \\
\pm 3.5\end{array}$ \\
\hline $\begin{array}{l}\text { Saline } \\
\text { solu- } \\
\text { tion }\end{array}$ & - & 5 & $\begin{aligned} & 18.8^{*} \\
\pm & 0.5\end{aligned}$ & $\begin{array}{l}0.55^{*} \\
\pm 0.06\end{array}$ & $\begin{aligned} & 23.54^{*} \\
\pm & 1.64\end{aligned}$ & $\begin{aligned} & 0.264^{*} \\
+ & 0.039\end{aligned}$ & $\begin{array}{c}90.53^{*} \\
\pm 7.34\end{array}$ & $\begin{array}{l}1.68^{*} \\
\pm 0.09\end{array}$ & $\begin{array}{r}0.46 \\
\pm 0.05\end{array}$ & $\begin{aligned} & 0.65^{*} \\
\pm & 0.10\end{aligned}$ & $\begin{array}{l}0.70^{*} \\
+0.03\end{array}$ & $\begin{aligned} & 1.47^{*} \\
+ & 0.17\end{aligned}$ & $\begin{array}{l}12.9^{*} \\
+1.4\end{array}$ \\
\hline $\begin{array}{c}\text { Bame- } \\
\text { than }\end{array}$ & $2.5 \times 10^{-4}$ & 3 & $\begin{array}{l}17.7^{*} \\
\pm 1.2\end{array}$ & $\begin{array}{l}0.67^{*} \\
\pm 0.03\end{array}$ & $\begin{array}{l}23.39^{*} \\
\pm 2.71\end{array}$ & $\begin{array}{l}0.249^{*} \\
\pm 0.024\end{array}$ & $\begin{array}{l}93.80^{*} \\
\pm 0.09\end{array}$ & $\begin{array}{l}1.76^{*} \\
\pm 0.03\end{array}$ & $\begin{array}{r}0.49 \\
\pm 0.12\end{array}$ & $\begin{array}{l}0.51^{*} \\
\pm 0.08\end{array}$ & $\begin{array}{l}0.73^{*} \\
\pm 0.01\end{array}$ & $\begin{aligned} & 1.38^{*} \\
\pm & 0.25\end{aligned}$ & $\begin{array}{l}18.4^{* \dagger}+ \\
\pm 1.5\end{array}$ \\
\hline $\mathrm{DCI}$ & $5.0 \times 10^{-4}$ & 3 & $\begin{array}{l}17.6^{*} \\
\pm 0.9\end{array}$ & $\begin{array}{l}0.51^{*} \\
\pm 0.08\end{array}$ & $\begin{array}{c}23.68^{*} \\
\pm 2.43\end{array}$ & $\begin{array}{l}0.252^{*} \\
\pm 0.032\end{array}$ & $\begin{array}{r}94.65^{*} \\
\pm 3.06\end{array}$ & $\begin{aligned} & 1.48^{*} \\
\pm & 0.11\end{aligned}$ & $\begin{array}{r}0.50 \\
\pm 0.02\end{array}$ & $\begin{array}{l}0.72^{*} \\
\pm 0.06\end{array}$ & $\begin{aligned} & 0.63^{*} \\
\pm & 0.03\end{aligned}$ & $\begin{aligned} & 1.20^{*} \\
\pm & 0.09\end{aligned}$ & $\begin{array}{r}11.2^{*} \\
\pm 1.5\end{array}$ \\
\hline $\begin{array}{l}\text { Papa- } \\
\text { verine }\end{array}$ & $5.0 \times 10^{-4}$ & 3 & $\begin{array}{c}19.0^{*} \\
\pm 0.6\end{array}$ & $\begin{array}{r}0.59^{*} \\
\pm 0.07\end{array}$ & $\begin{array}{c}22.63^{*} \\
\pm 1.80\end{array}$ & $\begin{aligned} & 0.258^{*} \\
\pm & 0.030\end{aligned}$ & $\begin{array}{c}88.56^{*} \\
\pm 3.28\end{array}$ & $\begin{array}{r}1.82^{*} \\
\pm 0.12\end{array}$ & $\begin{array}{r}0.49 \\
\pm 0.04\end{array}$ & $\begin{array}{l}0.56^{*} \\
\pm 0.02\end{array}$ & $\begin{array}{r}0.72^{*} \\
\pm 0.01\end{array}$ & $\begin{aligned} & 1.81^{*} \\
\pm & 0.15\end{aligned}$ & $\begin{array}{l}16.4^{*} \\
\pm 2.2\end{array}$ \\
\hline
\end{tabular}

Mean values $\pm \mathrm{SE}$ of $n$ preparations (four assays per preparation). The energy charge potential (ECP) was calculated as: ([ATP] 0.5 [ADP]) $([\mathrm{ATP}]+[\mathrm{ADP}]+[\mathrm{AMP}])$. The drugs were perfused through the superior thyroid arteries, at the rate $0.5 \mathrm{ml} / \mathrm{min}$ for six $\mathrm{minutes}{ }^{*} \mathrm{Statistica}{ }^{2}$ difference $(P<0.05)$ versus the value of control condition at $\mathrm{PaO}_{2}=96.4 \mathrm{~mm} \mathrm{Hg}$. + Statistical difference $(P<0.05)$ versus the value of hypoxaemiag condition at $\mathrm{PaO}_{2}=18.8 \mathrm{mmHg}$.

TABLE 2

CEREBRAL CORTEX OF MOTOR AREA OF BEAGLE DOG IN HYPOVOLAEMIC HYPOTENSION: BEHAVIOUR OF SOME BIOCHEMICAL PARAMETERS DURING POST-HYPOXIC RECOVERY

\begin{tabular}{|c|c|c|c|c|c|c|c|c|c|c|c|c|}
\hline \multirow[t]{2}{*}{$\begin{array}{l}\text { Experimental } \\
\text { conditions }\end{array}$} & \multirow[b]{2}{*}{$(n)$} & \multirow{2}{*}{$\begin{array}{l}\mathrm{PaO}_{2} \\
(\mathrm{mmHg})\end{array}$} & Glycogen & Lactate & Pyruvate & \multirow{2}{*}{$\begin{array}{l}\text { Lactate: } \\
\text { pyruvate } \\
\text { ratio }\end{array}$} & $A T P$ & $A D P$ & $A M P$ & \multirow[t]{2}{*}{$E C P$} & \multirow{2}{*}{$\begin{array}{c}\text { Cyclic } \\
\text { AMP } \\
(\text { nmol.g } \\
-1)\end{array}$} & \multirow{2}{*}{$\begin{array}{r}\text { Adenyl } \\
\text { cyclase } \\
\text { activity } \\
\left(m U \cdot g^{-1}\right.\end{array}$} \\
\hline & & & \multicolumn{3}{|c|}{$\left(\mu \mathrm{mol} . \mathrm{g}^{-1}\right)$} & & \multicolumn{3}{|c|}{$\left(\mu \mathrm{mol} \cdot \mathrm{g}^{-1}\right)$} & & & \\
\hline Hypoxaemia & 5 & $\begin{array}{l}18.8^{*} \\
\pm 0.5\end{array}$ & $\begin{array}{r}0.55 \\
\pm 0.06\end{array}$ & $\begin{array}{l}23.54^{*} \\
\pm 1.64\end{array}$ & $\begin{aligned} & 0.264^{*} \\
\pm & 0.039\end{aligned}$ & $\begin{array}{r}90.53 \\
\pm 7.34\end{array}$ & $\begin{aligned} & 1.68^{*} \\
\pm & 0.09\end{aligned}$ & $\begin{array}{r}0.46 \\
\pm 0.05\end{array}$ & $\begin{array}{l}0.65^{*} \\
\pm 0.10\end{array}$ & $\begin{array}{l}0.70^{*} \\
\pm 0.03\end{array}$ & $\begin{array}{r}1.47 \\
\pm 0.17\end{array}$ & $\begin{array}{l}12.9^{*} \\
\pm 1.4\end{array}$ \\
\hline $\begin{array}{l}3 \text { min after recovery } \\
\text { of room air }\end{array}$ & 5 & 97.8 & 0.46 & 13.4 & 0.163 & 87.54 & 2.00 & 0.56 & 0.36 & 0.78 & 1.91 & 15.3 \\
\hline $\begin{array}{l}\text { ventilation } \\
\text { Idem }+\end{array}$ & 3 & $\begin{array}{l} \pm 1.6 \\
97.7\end{array}$ & $\begin{array}{r} \pm 0.06 \\
0.41\end{array}$ & $\begin{array}{r} \pm 1.2 \\
13.8\end{array}$ & $\begin{array}{r} \pm 0.015 \\
0.178\end{array}$ & $\begin{array}{r} \pm 14.69 \\
79.43\end{array}$ & $\begin{aligned} \pm 0.05 \\
1.95\end{aligned}$ & $\begin{array}{r} \pm 0.04 \\
0.45\end{array}$ & $\begin{array}{r} \pm 0.03 \\
0.22\end{array}$ & $\begin{array}{r} \pm 0.01 \\
0.83\end{array}$ & \pm 0.16 & $\begin{array}{r} \pm 1.9 \\
20.4\end{array}$ \\
\hline $\begin{array}{l}\text { bamethan } \\
\left(2.5 \times 10^{-4} \mathrm{M}\right)\end{array}$ & & \pm 2.3 & \pm 0.03 & $\begin{array}{l}1.0 \\
\pm 2.8\end{array}$ & \pm 0.029 & $\begin{array}{l}13.89 \\
\end{array}$ & \pm 0.08 & $\begin{array}{r}0.45 \\
\pm 0.05\end{array}$ & $\begin{array}{r}0.22 \\
\pm 0.01\end{array}$ & $\begin{array}{r}0.83 \\
\pm 0.01\end{array}$ & \pm 0.27 & $\begin{array}{r}20.4 \\
\pm 2.2\end{array}$ \\
\hline $\begin{array}{l}\text { Idem }+ \\
\text { DCI }\left(5 \times 10^{-4} \mathrm{M}\right) \\
\text { Idem }+\end{array}$ & 3 & $\begin{array}{r}96.7 \\
\pm 3.4\end{array}$ & $\begin{array}{r}0.62 \\
\pm 0.06\end{array}$ & $\begin{array}{r}16.6 \\
\pm 0.3\end{array}$ & $\begin{array}{r}0.192 \\
\pm 0.037\end{array}$ & $\begin{array}{r}103.88 \\
\pm 17.72\end{array}$ & $\begin{array}{r}1.91 \\
\pm 0.02\end{array}$ & $\begin{array}{r}0.55 \\
\pm 0.04\end{array}$ & $\begin{array}{r}0.37 \\
\pm 0.05\end{array}$ & $\begin{array}{r}0.77 \\
\pm 0.01\end{array}$ & $\begin{aligned} & 1.30^{*} \\
\pm & 0.17\end{aligned}$ & $\begin{array}{r}11.4 \\
\pm 1.8\end{array}$ \\
\hline $\begin{array}{l}\text { DCI }\left(5 \times 10^{-4} \mathrm{M}\right)+ \\
\text { bamethan } \\
\left(2.5 \times 10^{-4} \mathrm{M}\right)\end{array}$ & + & $\begin{array}{r}97.3 \\
\pm 2.6\end{array}$ & $\begin{array}{r}0.59 \\
\pm 0.10\end{array}$ & $\begin{array}{r}13.6 \\
\pm I .8\end{array}$ & $\begin{array}{r}0.179 \\
\pm 0.010\end{array}$ & $\begin{array}{r}77.63 \\
\pm 14.50\end{array}$ & $\begin{array}{r}1.98 \\
\pm 0.06\end{array}$ & $\begin{array}{r}0.55 \\
\pm 0.03\end{array}$ & $\begin{array}{r}0.42 \\
\pm 0.02\end{array}$ & $\begin{array}{r}0.76 \\
\pm 0.01\end{array}$ & $\begin{array}{l}1.26 * \\
\pm 0.16\end{array}$ & $\begin{array}{r}11.0 \\
\pm 0.6\end{array}$ \\
\hline $\begin{array}{l}\text { Idem }+ \\
\quad \text { papaverine } \\
\left(5 \times 10^{-4} \mathrm{M}\right)\end{array}$ & 3 & $\begin{array}{r}98.0 \\
+2.5\end{array}$ & $\begin{array}{r}0.40 \\
\pm 0.01\end{array}$ & $\begin{array}{r}14.3 \\
\pm 2.2\end{array}$ & $\begin{array}{r}0.189 \\
+0.009\end{array}$ & $\begin{array}{r}74.80 \\
\pm 7.65\end{array}$ & $\begin{array}{r}1.94 \\
\pm 0.04\end{array}$ & $\begin{array}{r}0.54 \\
\pm 0.02\end{array}$ & $\begin{array}{r}0.37 \\
\pm 0.03\end{array}$ & $\begin{array}{r}0.78 \\
\pm 0.02\end{array}$ & $\begin{array}{r}2.36 \\
\pm 0.54\end{array}$ & $\begin{array}{r}14.5 \\
\pm 2.9\end{array}$ \\
\hline $\begin{array}{l}\text { Pre-hypoxia } \\
\text { control condition }\end{array}$ & 5 & $\begin{array}{r}96.4 \\
\pm 2.3\end{array}$ & $\begin{aligned} & 3.04^{*} \\
\pm & 0.19\end{aligned}$ & $\begin{array}{l}2.28^{*} \\
\pm 0.10\end{array}$ & $\begin{array}{l}0.122^{*} \\
\pm 0.009\end{array}$ & $\begin{array}{l}18.85^{*} \\
\pm 0.67\end{array}$ & $\begin{array}{r}2.28 \\
\pm 0.06\end{array}$ & $\begin{array}{r}0.45 \\
\pm 0.03\end{array}$ & $\begin{array}{l}0.09^{*} \\
\pm 0.01\end{array}$ & $\begin{array}{l}0.89^{*} \\
\pm 0.01\end{array}$ & $\begin{array}{r}3.22 * \\
\pm 0.23\end{array}$ & $\begin{array}{l}25.2^{*} \\
\pm 1.5\end{array}$ \\
\hline
\end{tabular}

Mean values \pm SE of $n$ preparations (four assays per preparation). The energy charge potential (ECP) was calculated as: ([ATP] + 0.5 [ADP])/ $([\mathrm{ATP}]+[\mathrm{ADP}]+[\mathrm{AMP}])$. The drugs were perfused through the superior thyroid arteries, at the rate of $0.5 \mathrm{ml} / \mathrm{min}$, for three minutes. * Statistical difference $(P<0.05)$ versus the value of three minute recovery of room air ventilation, at $\mathrm{PaO}_{2}=97.8 \mathrm{mmHg}$. 


\section{RESULTS}

Table 1 shows how the progressive decrease of arterial $\mathrm{pO}_{2}$ induced biochemical changes in the cortex of the motor area of the brain. The decrease of the arterial oxygen pressure to about $25 \mathrm{mmHg}$ induced a marked degradation of cerebral glycogen, and an increase of both adenyl cyclase activity and cyclic AMP tissue concentration. Consequently, the catabolism of cerebral glycogen is increased by the cyclic AMP activated system. Under this condition, the pattern of the increase of the cerebral lactate:pyruvate ratio was discharged from that of the energy charge potential, which was unchanged. This indicates that the increase in the lactate production from glycogenolysis helped to maintain the energy charge potential of the adenylate system at the steady state level.

When the arterial oxygen pressure fell to a value below $20 \mathrm{mmHg}$ (Table 1), the acute hypoxaemia strongly modified overall brain metabolism. The further drop of the cerebral glycogen content was accompanied by a marked reduction of the adenyl cyclase activity and cyclic AMP level. Both the lactate concentration and the lactate:pyruvate ratio increased dramatically, thus indicating the activation of glycolysis.

At $\mathrm{pO}_{2}$ value below $20 \mathrm{mmHg}$ (Table 1), the intracarotid perfusion of the $\beta$-adrenergic stimulating agent bamethan (Table 1) caused an increase in the adenyl cyclase activity, but not a concomitant increase in the cyclic AMP concentration; the cerebral energy charge potential remained highly depressed. The intracarotid perfusion of the $\beta$-adrenergic blocking agent $D C I$ exerted no effect on the biochemical changes induced by hypoxaemia. The vasodilator agent papaverine did not affect the drop of the energy charge potential induced by hypoxaemia.

Table 2 shows the data evaluated three minutes after the post-hypoxia recovery. The biochemical pattern was shifted and a partial recovery of the cerebral energy charge potential occurred. The redox state of the brain, as measured by the lactate:pyruvate ratio, remained high, thus indicating the persistence of anaerobic mechanism. The perfusion of the $\beta$-adrenergic stimulating agent bamethan induced an increase of the adenyl cyclase activity and the cyclic AMP level. On the contrary, the perfusions of the $\beta$-adrenergic blocking agent DCI and of DCI + bamethan blocked the recovery of the activity of the adenyl cyclase system. This indicates the importance of a $\beta$-adrenergic activation on the energy-coupling processes in vivo. The intracarotid perfusion of the vasodilator agent papaverine exhibited no effect on the biochemical changes induced by the recovery of air ventilation.

\section{DISCUSSION}

Before discussing the present results, some limitations should be pointed out. In the first place, the model used was an acute one: consequently, chronic studies might lead to different biochemical adjustments. Secondly, these data refer to the motor area of the cerebral cortex: therefore, other important areas of the brain might undergo different biochemical adjustments, because of the anatomical and functional heterogeneity of the brain.

In a first stage induced by hypoxaemia, at values of arterial $\mathrm{O}_{2}$ partial pressure higher than $25 \mathrm{mmHg}$, the activation of the cerebral adenyl cyclase system seems to be a very important biochemical way for increasing glycogen metabolism, its utilization being strongly modulated by both the enzyme activity and the cyclic AMP level. The increase of the lactate:pyruvate ratio in the cerebral tissue is a function of the decrease of arterial oxygen pressure.

In a second stage induced by hypoxaemia, at values of arterial $\mathrm{O}_{2}$ partial pressure lower than $20 \mathrm{mmHg}$, a critical threshold was probably exceeded, new biochemical conditions were established, and other biochemical mechanisms of regulation were involved. In fact, the adenyl cyclase system was cut off, while carbohydrate catabolism was high, as indicated by the very high lactate production, by the very high lactate: pyruvate ratio, and by the further glycogen reduction. In any case the low ATP levels reduced the substrate for cyclic AMP formation, while they enhanced the rate of transformation from inactive to active phosphofructokinase. On the other hand, the phosphorylase activation can be supported by tissue factors-for example, the kinase activating factor. In any case, during this condition, the $\beta$-adrenergic stimulation, the $\beta$ - 
adrenergic block or the vasodilatation exhibited no action on the cerebral energy charge. This indicates that the physiological autoregulation and feed-back phenomena overcome exogenous interventions. The $\beta$-adrenergic stimulation can induce an increase in the adenyl cyclase activity but not an increase in the cyclic AMP level, probably because of the impairment of ATP.

During the post-hypoxic restoration, the cerebral energy charge potential exhibited a gradual recovery. The high lactate:pyruvate ratio indidicated that the mechanism involved in the recharging of the adenylate pool was still partially anaerobic. Perfusion with a $\beta$-receptor stimulating agent potentiated the adenyl cyclase system and increased the cerebral level of cyclic AMP. Perfusion of a $\beta$-receptor blocking agent inhibited the activation by a $\beta$-stimulating agent. This fact is probably related to the block of the adenyl cyclase receptor, the adenyl cyclase protein being regarded as a $\beta$-adrenergic receptor (Robison et al., 1967). No correlations exist between the vasodilator effect and the recovery of the cerebral energy-coupling systems. Though a strong vasodilator, papaverine proved unable to affect favourably the restoration of the cerebral energy charge potential.

In conclusion, the data obtained indicate that the adenyl cyclase system is an important cerebral biochemical regulatory factor, but that this system becomes less important beyond a critical threshold of arterial oxygen partial pressure (lower than 25-20 $\mathrm{mmHg}$ ). Under these conditions, other enzymatic systems-for example, phosphofructokinase-intervene as rate-limiting factors in glycolysis. Consequently, during hypoxaemia the cerebral adenyl cyclase system seems to play a role as an activating factor, but is unable to sustain the activating step for long periods of time beyond a $\mathrm{pO}_{2}$ critical threshold.

\section{REFERENCES}

Ariens, E. J. (1966). Receptor theory and structure-action relationships. Advances in Drug Research, 3, 235-285.

Atkinson, D. E. (1968). The energy charge of the adenylate pool as regulatory parameter. Interaction with feed-back modifiers. Biochemistry, 7, 4030-4034.

Aulich, A., Stock, K., and Westermann, E. (1967). Lipolytic effects of cyclic adenosine $3^{\prime}, 5^{\prime}$-monophosphate and its butyryl derivatives in vitro, and their inhibition by alpha and beta-adrenolytics. Life Sciences, 6, 929-938.

Benzi, G., Arrigoni, E., Manzo, L., De Bernardi, M., Ferrara, A., Panceri, P., and Berte, F. (1973). Estimation of changes induced by drugs in cerebral energy-coupling processes in situ in the dog. Journal of Pharmaceutical Sciences, 62, 758-764.

Biver, A., and Goffart, M. (1965). L'action potentiatrice de l'adrénaline sur la contraction du muscle strié de mammifère est-elle un effet de type alpha ou beta? Archives Internationales des Pharmacodynamie et de Thérapie, 158, 59-72.

Bowman, W. C., and Raper, C. (1967). Adrenotropic receptors in skeletal muscle. Annals of the New York Academy of Sciences, 139, 741-753.

Breckenridge, B. M., Burn, J. H., and Matschinsky, F. M. (1967). Theophylline, epinephrine and neostigmine facilitation of neuromuscular transmission. Proceedings of the National Academy of Sciences of the United States of America, 57, 1893-1897.

Butcher, R. W., and Sutherland, E. W. (1962). Adenosine $3^{\prime}, 5^{\prime}$-phosphate in biological materials. 1. Purification and properties of cyclic 3', 5'-nucleotide phosphodiesterase and use of this enzyme to characterize adenosine $3^{\prime}, 5^{\prime}-$ phosphate in human urine. Journal of Biological Chemistry, 237, 1244-1250.

Butcher, R. W., and Sutherland, E. W. (1967). The effects of the catecholamines adrenergic blocking agents, prostaglandin $E_{1}$, and insulin on cyclic AMP levels in the rat epididymal fat pad in vitro. Annals of the New York Academy of Sciences, 139, 849-859.

Butcher, R. W., Ho, R. J., Meng, C., and Sutherland, E. W. (1965). Adenosine 3', 5'-monophosphate in biological materials. 2. The measurement of adenosine 3', 5'-monophosphate in tissues and the role of the cyclic nucleotide in the lipolytic response of fat to epinephrine. Journal of Biological Chemistry, 240, 4515-4523,

Cheung, W. Y. (1967). Properties of cyclic $3^{\prime}-5^{\prime}$ nucleotide phosphodiesterase from rat brain. Biochemistry, 6, 10791087.

De Robertis, E., Rodriguez de Lores Arnaiz, G., Alberici, M., Butcher, R. W., and Sutherland, E. W. (1967). Subcellular distribution of adenyl cyclase and cyclic phosphodiesterase in rat brain cortex. Journal of Biological Chemistry, 242, 3487-3493.

Grahame-Smith, D. G., Butcher, R. W., Ney, R. L., and Sutherland, E. W. (1967). Adenosine 3', 5'-monophosphate as the intracellular mediator of the action of adrenocorticotropic hormone on the adrenal cortex. Journal of Biological Chemistry, 242, 5535-5541.

Hohorst, H. J., Kreutz, F. H., and Bucher, T. (1959). Über Metabolitgehalte und Metabolit-Konzentrationen in der Leber der Ratte. Biochemische Zeitschrift, 332, 18-46.

Holmin, T., Johannsson, H., and Siesjö, B. K. (1974). Effects on cerebral energy state of arterial hypotension in rats with porta-caval anastomosis. Acta Physiologica Scandinavica, 90, 345-357.

Kakiuchi, S., and Rall, T. W. (1968). The influence of chemical agents on the accumulation of adenosine-3', 5'-phosphate in slices of rabbit cerebellum. Molecular Pharmacology, 4, 367-378.

Klainer, L. M., Chi, Y. M., Friedberg, S. L., Rall, T. W., and Sutherland, E. W. (1962). Adenyl cyclase. 4. The effects of neurohormones on the formation of adenosine $3^{\prime}, 5^{\prime}$ phosphate by preparations from brain and other tissues. Journal of Biological Chemistry, 237, 1239-1243.

Le Baron, F. N. (1955). The resynthesis of glycogen by guinea-pig cerebral cortex slices. Biochemical Journal, 61, 80-85.

Lowry, O. H., Passonneau, J. V., Hasselberger, F. X., and Schultz, D. W. (1964). Effect of ischemia on known substrates and cofactor of the glycolytic pathway in brain. Journal of Biological Chemistry, 239, 18-30. 
Minard, F. N., and Davis, R. V. (1962). The effects of electroshock on the acid-soluble phosphates of rat brain. Journal of Biological Chemistry, 237, 1283-1289.

Northrop, G., and Parks, R. E. (1964). The effects of adrenergic blocking agents and theophylline on $3^{\prime}, 5^{\prime}$-AMPinduced hyperglycemia. Journal of Pharmacology and Experimental Therapy, 145, 87-91.

Robison, G. A., Butcher, R. W., and Sutherland, E. W. (1967). Adenyl cyclase as an adrenergic receptor. Annals of the New York Academy of Sciences, 139, 703-723.

Schmahl, F. W., Bertz, H., Talke, H., and Hohorst, H. J. (1965). Energiereiche Phosphate und Metabolite des Energiestoffwechsels in der Grosshirnrinde der Katze. Biochemische Zeitschrift, 342, 518-531.

Schmidt, F. H. (1961). Die enzymatische Bestimmung von
Glucose und Fructose Nebeneinander. Klinische Wochenschrift, 39, 1244-1247.

Siesjö, B. K., and Nilsson, L. (1971). The influence of arterial hypoxemia upon labile phosphates and upon extracellular and intracellular lactate and pyruvate concentrations in the rat brain. Scandinavian Journal of Clinical and Laboratory Investigation, 27, 83-96.

Stock, K., and Westermann, E. (1966). Hemmung der Lipolyse durch alpha und beta-Sympathicolytica, Nicotinsäure und Prostaglandin $\mathrm{E}_{1}$. Archiv für Experimentelle Pathologie und Pharmakologie, 254, 334-354.

Sutherland, E. W., Rall, T. W., and Menon, T. (1962). Adenyl cyclase. I. Distribution, preparation and properties. Journal of Biological Chemistry, 237, 1220-1227.

Villa, R. F. (1975). Effect of hypoxia on the cerebral energy state. Il Farmaco, Ed.Sc., 30, 561-567. 